Agro-Science Journal of Tropical Agriculture, Food, Environment and Extension Volume 19 Number 2 (Apr. 2020) pp. 23 - 30

ISSN 1119-7455

\title{
EFFECT OF SLOPE ASPECT AND POSITION ON SOIL INFILTRABILITY IN AN ULTISOL IN AKWA IBOM STATE, SOUTHERN NIGERIA
}

\author{
*gban P.I. and Okon A.X. \\ Department of Soil Science \& Land Resources Management, \\ Faculty of Agriculture, University of Uyo, Uyo, Nigeria \\ *Corresponding author's email: peterogban@yahoo.com, peterogban55@gmail.com
}

\begin{abstract}
Soil infiltrability is an important hydrological process that enhances soil water storage and the minimization of runoff. A study was conducted to evaluate the effect of slope aspect (north, NfS and south, SfS) and positions [(crest (CR), upper (US), middle (MS) and lower (LS)] on soil infiltrability, that is, initial infiltration rate $\left(i_{o}\right)$, steady-state infiltration rate $\left(i_{c}\right)$ and cumulative infiltration $(I)$, and sorptivity $(S)$ and transmissivity (A) on the University of Uyo Teaching and Research Farm $(T \& S F)$ located on an Ultisol in Akwa Ibom State, southern Nigeria. Results show that the initial infiltration rate $\left(i_{o}\right)$ was $43.20 \mathrm{~cm} \mathrm{~h}^{-1}$ on SfS and significantly $(p<0.05)$ higher than $36.60 \mathrm{~cm} \mathrm{~h}^{-1}$ on NfS. The final infiltration rate $\left(i_{c}\right)$ was not significantly different between NfS $\left(9.60 \mathrm{~cm} \mathrm{~h}^{-1}\right)$ and $S f S\left(7.20 \mathrm{~cm} \mathrm{~h} \mathrm{~h}^{-1}\right)$. The Cumulative depth of water (I) infiltrated was similar between NfS $(28.18 \mathrm{~cm})$ and SfS $(21.46 \mathrm{~cm})$. Soil water sorptivity $(S)$ was moderately high on the two slopes but significantly $(p<0.05)$ lower in NfS $\left(0.49 \mathrm{~cm} \mathrm{~min}^{-1 / 2}\right)$ than in SfS $\left(0.70 \mathrm{~cm} \mathrm{~min}^{-1 / 2}\right)$ soil. Soil water transmissivity $(A)$ was similar in $N f S\left(0.19 \mathrm{~cm} \mathrm{~h}^{-1}\right)$ and $S f S\left(0.16 \mathrm{~cm} \mathrm{~h}^{-1}\right)$ soil. The results indicate that the aspects were similar in $i_{o}, i_{c}, I, S$ and A. However, since soil texture is similar among the aspects, similar soil management practices, example tillage and mulching, could be adopted to enhance water infiltration to improve $i_{c}$ for increases in soil water conservation and crop production on the $T \& S F$.
\end{abstract}

Key words: slope aspect and position, soil infiltrability, sorptivity and transmissivity, soil water management

\section{INTRODUCTION}

Soil infiltrability is an important hydrological process in the vadose zone, the unsaturated zone of soils (Lal and Shukla, 2005; Shukla, 2014). It is related to the timing and amount of runoff during a rainstorm, root zone water storage and groundwater recharge (Pla, 2007), the entrainment of passenger chemicals (nutrients and pollutants) dissolved in it, and soil erosion and sustainable food production (Moore et al., 1981; Shukla, 2011). Quantification of infiltration is necessary to determine the availability of water to crops and to estimate the amount of additional water needed for irrigation, evaluating the surface and groundwater resources, determining the needed irrigation parameters ( $\mathrm{Li}$ et $a l ., 2009)$, and for identifying water conservation strategies and runoff and erosion control practices (Shukla et al., 2003). It is for these reasons that infiltration has been the research focus over the years (Green and Ampt, 1911; Philip, 1957; Wooding, 1968; Brutsaert, 1977).

The principal parameters of infiltration are soil infiltrability and cumulative infiltration which are related by Equation 1:

$$
i=\frac{d I}{d t}
$$

where $i$ is the infiltration rate $\left(\mathrm{cm} \mathrm{min}{ }^{-1}\right) ; t$ is the time (min) with $t=0$ at the beginning of the infiltration process; $I$ is the cumulative infiltration or equivalent depth of water $(\mathrm{cm})$. The infiltration rate is the flux density of water flowing into the soil per unit time when water at atmospheric pressure is made freely available at the soil surface (Hillel, 1971). The infiltrability approached after a sufficiently large time (Horton, 1940), is a measure of the extent a given soil under specified surface and profile conditions can take in water. The cumulative amount is the time integral of the infiltration rate (Hillel, 1971); its prediction is important in understanding the amount of water entering and its distribution in the soil. Thus, infiltration integrates three independent processes: (i) entry through the soil surface; (ii) storage within the soil, and (iii) transmission through the soil (Dunne and Leopold, 1978) all of which combine to influence soil quality, e.g., its ability for agronomic productivity.

The ability of a soil to accept the influx of water is controlled by soil biophysical interacting forces that create a stable soil structure with enough macropores to rapidly transmit water. Soil infiltrability is a surrogate of many other soil properties which can exert a direct influence on the 
stability of the land surface. That is, soil infiltrability is a reflection of the inherent properties of the soil predominantly soil texture and soil structure which affect pore geometry and organic matter content (Lal and van Doren, 1990; Franzluebbers, 2002), antecedent soil moisture content and matric potential in the vadose zone. Saxton et al. (1986) stated that soil texture and structure are the predominant factors affecting water infiltration into soils. For this reason, soil texture and structure are uniquely important in the prediction of infiltration rate and water retention (Philip, 1973; Arya et al., 1999a,b). Thus, factors that adversely affect soil structure and soil texture will as well affect soil water storage and availability to crops.

Land use and soil management primarily change soil structure and alter pore geometry and pore-size distribution and thus soil infiltrability (Lal and Shukla, 2005). Sharma et al. (1980) and Tricker (1981) stated that soil management has a more pronounced effect on infiltration than soil type. Soil that is continually disturbed by tillage and other anthropogenic activities often loses its resilience and develops poor structural characteristics, including surface sealing and crusting. This is because intensified land use primarily affects soil's intrinsic and dynamic properties including soil structure and structuremoderated soil properties. The consequence is reduced infiltration and high runoff and erosion. Ogban et al. (2000) had reported low values of the infiltration characteristics which indicated potentially high runoff (erosion) hazard, which would adversely affect the water economy of the plant rooting depth. Wuddivira et al. (2001) indicated that such soils would have difficulty in meeting the water requirements of crop where water is a limiting factor.

Research has shown that infiltration characteristics were closely related to soil structure and were a good indicator of changes in soil physical and biological properties under different soil use systems (Radke and Berry, 1993). Mukhtar et al. (1985) observed that the amount of water entering the soil was determined by the soil surface conditions including the presence of macropores. Mbagwu (1997) related soil bulk density with soil carbon and infiltrability. Davidoff and Selim (1986) reported that the infiltration characteristics of the soils they studied were influenced by residue addition, soil compaction and bulk density. Later, Mukhtar et al. (1985) and Radke and Berry (1993) concluded that soil use and management that include soil surface cover would maintain high soil infiltrability by reducing compaction from the impact of rainfall and crusting.

However, soil properties influencing soil water storage, runoff and erosion are significantly influenced by climate (rainfall characteristics), landscape features, including landscape position, topographic features (slope gradient), parent material and vegetation (Beckett and Webster, 1971; Jenny, 1980; Jungerius, 1985; Dunne et al., 1991) and surface conditions ( $\mathrm{Li}$ et al., 2011). It is common knowledge that topography influences soil characteristics (Ollinger et al., 2002; Yimer et al., 2006) because topography through its slope element drives geomorphic processes (Evans, 1972), and influences the fluxes of materials on and within the soil. However, studies on the effect of slope characteristics on soil surface features and properties have produced contrasting results between south aspects and north aspects (Coble et al., 2001). Geroy et al. (2011) reported that north aspect slope tended to be deeper and have greater soil porosity, soil organic matter and silt content than the opposing south aspect slope. Mukhtar et al. (1985) observed that the amount of water entering the soil increased proportionately with increased in the amount of macropores in the soil surface layer. Cerdia (1996) found infiltration rate was higher on the upper slope position than the middle slope or lower slope positions in South-east Spain. Guzman and Al-Kaisi (2011) reported that infiltration rates were much greater in the toe-slope than the summit. Gogo (2018) reported that soil infiltrability was significantly higher on the northfacing slope than on the south-facing slope on the coastal plain sands in southern Nigeria. Despite the effect of slope on soil processes, few studies have been conducted in the area on the relationship between soil infiltrability and slope characteristics. This study was conducted to evaluate the effect of slope aspect and position on soil infiltrability in order to guide soil use and water conservation for increases in crop production on the University of Uyo Teaching and Research Farm (T\&RF).

\section{MATERIALS AND METHODS}

\section{Study Area}

The study was conducted on the University of Uyo Teaching and Research Farm (T\&SF) at Use Offot, in Akwa Ibom State. The farm is located between latitudes $5^{\circ} 00^{\prime}$ and $5^{\circ} 10^{\prime}$ and longitudes $7^{\circ} 50^{\prime}$ and $8^{\circ} 00^{\prime}$.The farm is bisected by a dry valley between two moderately sloping aspects; a 5\% south-facing slope (SfS) and a 6\% north-facing slope (NfS).

The climate of the area is the hot humid tropical characterized by distinct wet and dry seasons (Inyang, 1975); the wet or rainy season generally lasts from April to October and the dry season lasts from November to March. The annual average rainfall may be over $3,500 \mathrm{~mm}$ with high peak intensities ranging from $60-120 \mathrm{~mm} \mathrm{~h}^{-1}$. The average annual temperature in the area is about $26^{\circ} \mathrm{C}$ and the relative humidity is about $70 \%$ (Petters et al., 1989). The area is located on the coastal plain sands geological formation with undulating topography and with gradients generally less than $5 \%$. The parent material consists of 
unconsolidated Coastal Plain Sands and the soils are classified as Ultisol in the USDA Soil Taxonomy system, corresponding to Acrisols or Alisols of the World Reference Base (FAO, 2014). The soils are deep, permeable, characterized by a narrow texture range having loamy sand to sandy loam surface layers over sandy clay loam to sandy clay subsoil, inherently low organic matter content (Ojanuga et al., 1981; Ofomata, 1981; Petters et al., 1989), and low structural stability (Ogban and Ekerette, 2001). A variety of soil-use practices, including forest, bush fallow, and cultivation are common, and soil use is the low input rainfed traditional farming that leaves more than $80 \%$ of the surface soil bare and exposed to the high intensity rainfall in the area (Petters et al., 1989; Udosen, 2017).

\section{Field Study}

The study was conducted on the $6 \% \mathrm{NfS}$ and $5 \%$ SfS, measured with the global positioning system (GPS).At the time of the study, the middle slope of $\mathrm{NfS}$ and crest of SfS were cultivated to cassava and pumpkin intercrop and garden egg, respectively. The crest of NfS was under a thirty-year oil palm plantation. Bare soil surface management is the rule on both slopes, a common practice in the area, subjecting the erodible soil on the slopes to the erosive rainfall. Other slope positions of NfS and SfS were under a two-year natural fallow.

A transect was taken from the crest to the valley bottom of each slope, each of which was then categorized into four slope positions, namely, crest, upper, middle and lower, at 20-m interval. At each slope position, three random soil samples were collected and bulked for the determination of particle-size fractions (PSF) and soil organic carbon (SOC) content. Two undisturbed core samples were also taken at each sampling point for the determination of bulk density (BD) and saturated hydraulic conductivity (Ksat).

Four infiltration runs were carried out at each slope position at intervals of $5 \mathrm{~m}$ across each transect, that is, perpendicular to slope, with the double ring infiltrometer (Reynolds et al., 2002) for a cumulative time of two hours. Measured cumulative infiltration was used to compute the infiltration rate $\left(i_{o}\right)$, steady-state infiltration $\left(i_{c}\right)$, and the curve-fitting procedure was used to obtain the soil sorptivity $(S)$, and soil transmissivity $(A)$ from Equation 1.

\section{Laboratory Study}

The bulk soil samples were analyzed in the laboratory for PSF (Gee and Or, 2002) and SOC (Sparks, 1996), while the core samples were used for Ksat and BD (Grossman and Reinsch, 2002) from which total pore space (TP) was computed (Flint and Flint, 2002).

\section{Statistical Analysis}

The means of the infiltration data were used to plot graphs of the effect of slope aspect and position on the infiltration process. The data were fitted into a split-plot in randomized complete block design and subjected to analysis of variance (ANOVA) at the $5 \%$ probability level for quantifying differences in the infiltration parameters among the slope aspects and positions. Also, Pearson's product moment correlation analysis was used to identify the soil properties influencing the infiltration characteristics on the $\mathrm{T}$ and $\mathrm{SF}$.

\section{RESULTS AND DISCUSSION \\ Effect of Slope and Aspect on Infiltration Characteristics}

The data of the effect of slope and slope position on soil physical properties are shown in Table 1, and the interaction of these properties with the infiltration characteristics is shown (Tables 3 and 4).

There was no consistent pattern of differences in the effect of slope aspect on the infiltration parameters (Table 2 and Figure 1). In Table 2 and Figures 1(a) NfS and 1(b) SfS, the initial infiltration rate $\left(i_{o}\right)$ was significantly $(p<0.05)$ higher on SfS $\left(0.72 \mathrm{~cm} \mathrm{~min}^{-1}\right.$ or $\left.43.20 \mathrm{~cm} \mathrm{~h}^{-1}\right)$ than NfS $\left(0.61 \mathrm{~cm} \mathrm{~min}^{-1}\right.$ or $\left.36.60 \mathrm{~cm} \mathrm{~h}^{-1}\right)$. Averaged over the slope positions (Figure 3), $i_{o}$ was about $0.60 \mathrm{~cm} \mathrm{~min}^{-1}\left(36 \mathrm{~cm} \mathrm{~h}^{-1}\right)$ on SfS and $0.50 \mathrm{~cm}$ $\min ^{-1}\left(30 \mathrm{~cm} \mathrm{~h}^{-1}\right)$ on NfS. Differences in $i_{o}$ on both slopes began to manifest at about $50 \mathrm{~min}$ from the commencement of the infiltration process. In other words, differences in $i_{o}$ appeared probably when the absorptive and capillary forces or hydraulic gradient began to diminish shown by the divergence in NfS and SfS. Although the slopes were similar in particle-size fractions (PSF) (Table 1), the higher in SfS soil was attributed to the inherent lower bulk density and significantly higher Ksat and OC than in NfS soil (Table 1). The higher $i_{o}$ on SfS compared to NfS may also be connected to their relative slope gradients: 5 vs $6 \%$, which indicates longer resident time and thus increases in infiltration on the former than on the latter slope. Compared to rainfall intensity of about $75 \mathrm{~mm} \mathrm{~h}^{-1}$ recorded in the area (Petters et al., 1989; Udosen, 2017), the $i_{o}$ values are high, indicating that even with continuous cultivation common on the T\&SF, the soils could continue to accept and transmit the rainwater for a cumulative time of about $125 \mathrm{~min}$ on NfS and SfS under the bare cultivation common on the farm.

The time-dependent infiltration process is generally governed by the Richards (1931) equation subject to the spatially variable physical conditions of the soil near the surface and the vertical soil matric-potential gradient at the onset of the process. Generally, the trend in infiltration rate in this study agreed with theory (Reynolds et al., 2002) because infiltration of water was rapid at the initial stages when the vadose zone was dry, with 
large suction gradients in both horizontal and vertical components of water flow, but rapidly decreased with time as soil became increasingly wet, i.e., matric potential increased, until it reached a steady state or near constant rate, which was attained at about a cumulative time of $125 \mathrm{~min}$ on $\mathrm{NfS}$ and SfS, and reflects the fact that steady-state conditions are attained at large times in coarsetextured soils. The decrease in infiltration rate with time may be due to reduction in moisture potential gradient, transient changes in soil structure through aggregate slaking, colloidal dispersion and clogging of the soil pores following tillage (Webster and Wilson, 1980) and repellency (Dekker and Ritsema, 1994). Lal (1986) observed that the infiltration rate of most upland soils declines with cultivation because of the rapid deterioration in soil structure and the susceptibility of these soils to surface crust and seal. In addition, Linsley et al. (1975) stated that the decreasing rate of infiltration with time of water application was due to the continuous diversion of gravity water into capillary-pore spaces by capillary forces.

The final infiltration rate $\left(i_{c}\right)$ was similar but higher on NfS $\left(0.16 \mathrm{~cm} \mathrm{~min}^{-1}\right.$ or $\left.9.6 \mathrm{~cm} \mathrm{~h}^{-1}\right)$ than SfS $\left(0.12 \mathrm{~cm} \mathrm{~min}^{-1}\right.$ or $\left.7.2 \mathrm{~cm} \mathrm{~h}^{-1}\right)$. Although both slopes attained $i_{c}$ at about $125 \mathrm{~min}$ from the outset of the infiltration process, it decreased faster on SfS than NfS. The $i_{c}$, besides the field water capacity, is a critical factor in irrigation management because it indicates the maximum rate of water application which in this study would be higher on NfS than $\mathrm{SfS}$. The values of $i_{c}$ are quite low compared to the rainfall amount and intensity in the area. The implication is that increases in soil water pressure potential, negates $i_{c}$ by limiting the capacity of the soil to accept rainwater on the farm. The limiting $i_{c}$ was also attributed to bare cultivation, especially the plough-harrow practice which allows soil particles to resettle to the state prior to tillage, as well as that it may, over the years, have resulted in the compaction of the lower soil layers which could not be remedied by the transient changes in soil structure and structure-moderated soil properties, e.g., bulk density, pore-size distribution, and hydraulic conductivity in the soil surface zone, following tillage. It also implies that when irrigation is adopted, water application may not exceed 9.6 and $7.2 \mathrm{~cm} \mathrm{~h}^{-1}$ on NfS and SfS, respectively, if soil erosion and degradation are to be avoided or minimized on the farm.

Table 2: Effect of slope aspect and position on infiltration characteristics in the University of Uyo T\&RF

\begin{tabular}{|c|c|c|c|c|c|}
\hline $\begin{array}{l}\text { Slope } \\
\text { position }\end{array}$ & $\begin{array}{l}i_{\mathrm{o}} \\
(\mathrm{cm} \mathrm{n}\end{array}$ & $\begin{array}{r}i_{\mathrm{c}} \\
\left.\mathrm{in}^{-1}\right)\end{array}$ & $\begin{array}{c}I \\
(\mathrm{~cm})\end{array}$ & $\begin{array}{c}S \\
\left(\mathrm{~cm} \mathrm{~min}^{-1 / 2}\right)\end{array}$ & $\begin{array}{c}A \\
\left(\mathrm{~cm} \mathrm{~min}^{-1}\right)\end{array}$ \\
\hline & \multicolumn{5}{|c|}{ Slope Aspect } \\
\hline NfS & 0.61 & 0.16 & $28.18^{1}$ & 0.49 & 0.19 \\
\hline SfS & 0.72 & 0.12 & 21.46 & 0.70 & 0.16 \\
\hline \multirow[t]{2}{*}{$\operatorname{LSD}_{(0.05)}$} & 0.10 & ns & ns & 0.15 & ns \\
\hline & \multicolumn{5}{|c|}{ Topographic Position } \\
\hline $\mathrm{CR}$ & 0.91 & 0.22 & 40.34 & 0.85 & 0.30 \\
\hline US & 0.63 & 0.12 & 20.90 & 0.53 & 0.15 \\
\hline MS & 0.59 & 0.11 & 20.69 & 0.52 & 0.15 \\
\hline LS & 0.54 & 0.10 & 17.35 & 0.48 & 0.11 \\
\hline \multirow[t]{2}{*}{$\operatorname{LSD}_{(0.05)}$} & 0.15 & 0.07 & 11.73 & 0.21 & 0.07 \\
\hline & & \multicolumn{4}{|c|}{ Slope Aspect $\times$ Position Interaction } \\
\hline NfS -CR & 1.05 & 0.33 & 59.38 & 0.86 & 0.41 \\
\hline NfS -US & 0.53 & 0.10 & 18.43 & 0.42 & 0.12 \\
\hline NfS -MS & 0.38 & 0.09 & 15.75 & 0.25 & 0.13 \\
\hline NfS -LS & 0.50 & 0.11 & 19.18 & 0.43 & 0.11 \\
\hline SfS-CR & 0.78 & 0.12 & 21.30 & 0.84 & 0.19 \\
\hline SfS-US & 0.73 & 0.13 & 23.38 & 0.63 & 0.17 \\
\hline SfS-MS & 0.80 & 0.14 & 25.63 & 0.80 & 0.17 \\
\hline SfS-LS & 0.58 & 0.09 & 15.53 & 0.53 & 0.10 \\
\hline $\operatorname{LSD}_{(0.05)}$ & 0.21 & 0.09 & 16.59 & 0.29 & 0.10 \\
\hline \multicolumn{6}{|c|}{$\begin{array}{l}\text { NfS - North-facing slope; SfS - South-facing slope; CR - crest; } \\
\text { US - upper slope; MS - middle slope; LS - lower slope; } i_{\mathrm{o}} \text { - initial } \\
\text { infiltration rate; } i_{c} \text { - final infiltration rate; } I \text { - cumulative infiltration; } \\
S \text { - sorptivity; } A \text { - transmissivity; LSD - least significant difference }\end{array}$} \\
\hline
\end{tabular}

Table 1: Effect of slope aspect and position on soil physical properties at the University of Uyo T\&RF

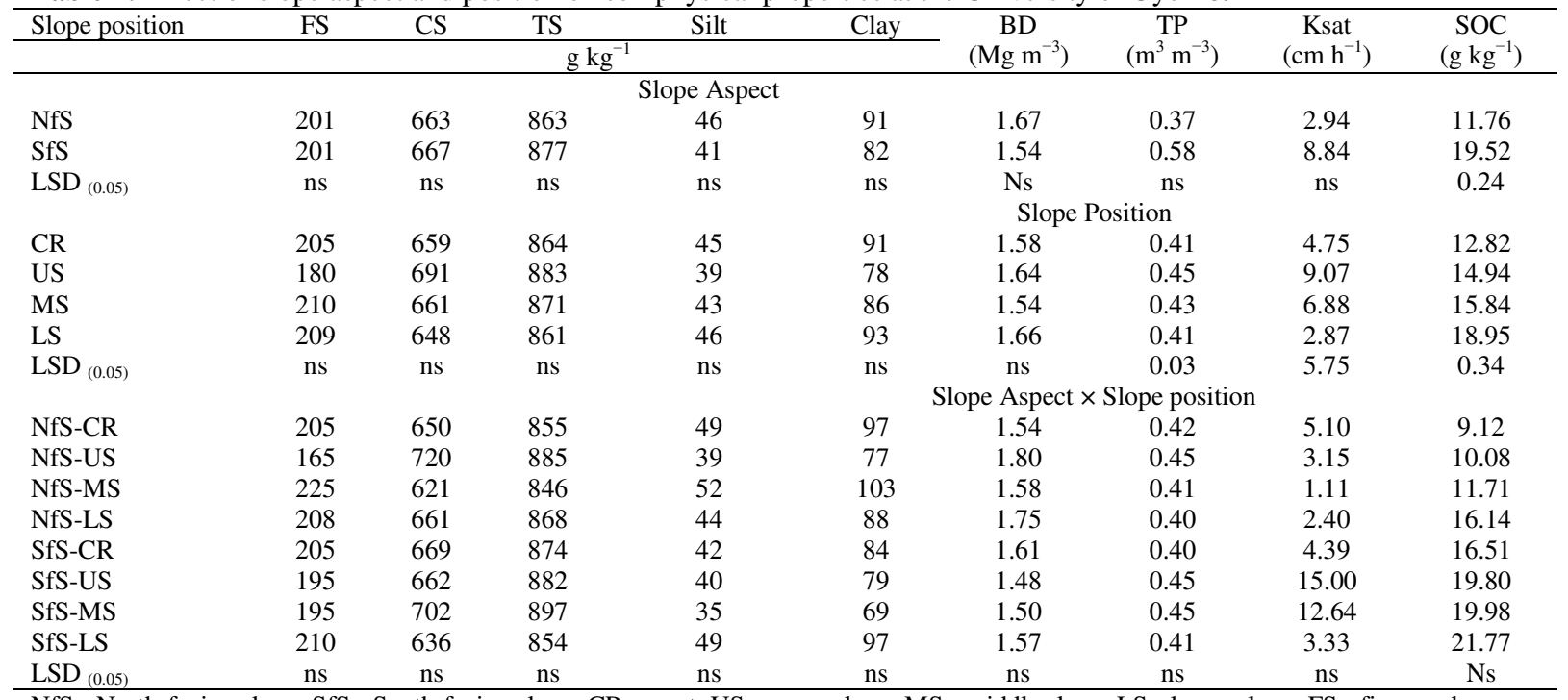

NfS - North-facing slope; SfS - South-facing slope; CR - crest; US - upper slope; MS - middle slope; LS - lower slope; FS - fine sand; CF - coarse sand; TS - total sand; BD - bulk density;TP - total porosity; Ksat - saturated hydraulic conductivity; SOC - soil organic carbon; LSD - least significant difference 


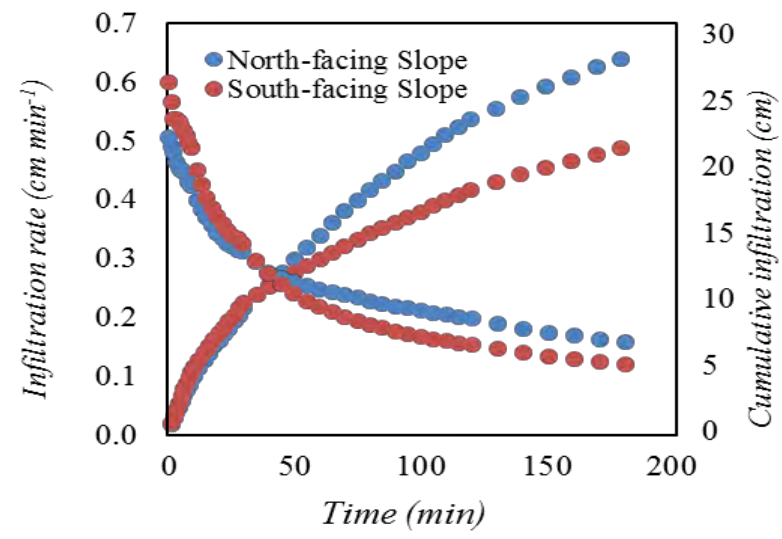

Figure 1: Effect of slope on infiltration rate and cumulative infiltration: north-facing slope (NfS) and (b) south-facing slope (SfS) at the University of Uyo T\&RF.

The cumulative depth of water (I) infiltrated after a cumulative time of $180 \mathrm{~min}$. was statistically similar but higher on NfS than SfS (Table 2 and Figure 1), and has a curvilinear time-dependence, with a gradually decreasing slope. From the outset of the infiltration process up to a cumulative time of $50 \mathrm{~min}$ (Figure 1), I was similar between NfS and SfS but thereafter diverged and became increasingly curvilinear. At a cumulative time of 50 min, both $i_{o}$ and $I$ appeared similar on both slopes and indicated a linear relationship between $i_{o}$ and $I$, that is, the soil would absorb rain or irrigation water in spite of their differences in soil properties. The cumulative time of $50 \mathrm{~min}$. corresponded to the point of sharp decline in $i_{o}$, probably due to aggregate slaking and sealing of pores and differences in subsoil profile characteristics influencing water transmission. The observed values of $I$ are low for the deeply permeable coarse-textured soils and indicate limiting plant available water holding capacity and ease of runoff which may adversely affect the water economy of the plant rooting depth (Wuddivira et al., 2001) and crop production on the T\&SF. Soil management practices such as mulch-tillage which will protect the surface and allow infiltration are needed on the farm.

Soil water sorptivity $(S)$ was moderately high on the two slopes but about $43 \%$ significantly $(p<0.05)$ lower in NfS than SfS soil (Table 2), and appeared to correlate with the lower bulk density and higher Ksat and SOC in SfS than in NfS soil. Sorptivity is a fieldsaturated water flow parameter, a measure of the ability of the soil to absorb water in the early stages of infiltration regulated by capillarity and surface tension forces (Philip, 1957) or a high vertical gradient in soil matric potential. Thus, sorptivity is a resistance factor that governs the early-stage infiltration (Bonsu, 1993; Stewart et al., 2013), and is related to $i_{o}$ and the potential for overland flow. The high $\mathrm{S}$, relative to $i_{o}$, is therefore due to the dominance of capillary forces within the soil. However, both $S$ and $i_{o}$, can be limited by the intensity of rainfall or rate of water supply to the field and the nature of the soil surface.
The fitted transmissivity, A, was similar in NfS and SfS soil but greater in the former than the latter (Table 2).Transmissivity, $A$, is a hydraulic property that is sensitive and related to changes in soil texture which in this study, becomes finer downslope (Table 1); soil texture also determines whether water transmission is capillarity- or gravity-driven (Reynolds et al., 2002). The lower values of $A$ compared with $S$ generally, indicated that soil texture facilitated capillarity-driven transmission and that it dominated water transmission in the soil profile. Transmissivity, $A$ is related to Ksat both of which are critical to soil's internal drainage. A often approaches Ksat at the later stages of infiltration, i.e., when $t \gg S^{2} / A^{2}$ (White et al., 1992). However, from the data in Tables 1 and 2, a definite relationship could not be established between $A$ and Ksat. With the average rainfall intensity of ca. $75 \mathrm{~mm} \mathrm{~h}^{-1}$ recorded in the area and that can occur within a 15-min. duration (Petters et al., 1989; Udosen, 2017), rainfall rate always exceeds infiltration rate as it declines from high to low values over the cumulative time-period, affecting accumulative infiltration, transmission and storage, and may explain the low $A$ recorded in the study.

\section{Effect of Slope Position on Infiltration Characteristics of the Soils}

The effect of slope position on $i_{o}$ averaged over NfS and SfS is shown in Table 2 and the effect on each slope is shown in Figure 2 (a) NfS and (b) SfS). In Table $2, i_{o}$ was significantly higher on the crest (CR) and decreases down the other slope positions (US, MS and LS); US, MS and LS were similar in their effects on $i_{o}$ but the pattern was US > MS > LS. In Figure 2 (a) NfS and (b) SfS), $i_{o}$ was significantly higher on CR and similar among other slope positions of NfS and all slope positions of SfS. The generally higher $i_{o}$ at CR irrespective of aspect was attributed to the fact that most crest landscape have flat to rolling nature that enhances infiltration than the lower members of the slope. The higher value of $i_{o}$ at CR of NfS was due to the oil palm forest with the associated root effect on soil porosity and water infiltration.

The depth of water infiltrated was significantly $(p<0.05)$ higher at CR than at all other slope positions of NfS and SfS; $I$ was similar among the latter slope positions (Table 2). In Figure 3(a), I was significantly $(p<0.05)$ higher on CR than US, MS and LS, but there were no differences among the slope positions in Figure 3(b). The trend in $I$ among the slope positions was $\mathrm{CR}$ > US > MS > LS. The lower cumulative infiltration observed downslope may indicate low capacity of the soil to hold water despite the higher clay content and organic carbon. Soil water sorptivity, $S$, was also significantly $(p<0.05)$ higher at CR than the other slope positions of NfS and SfS; differences among UP, MS and LS slope positions were not significant (Table 2). This indicates that much of rain water would infiltrate aided by absorptive and capillary forces into the soil, provided that the intake rate which averages $0.91 \mathrm{~cm} \mathrm{~min}^{-1}$, is not exceeded by the 

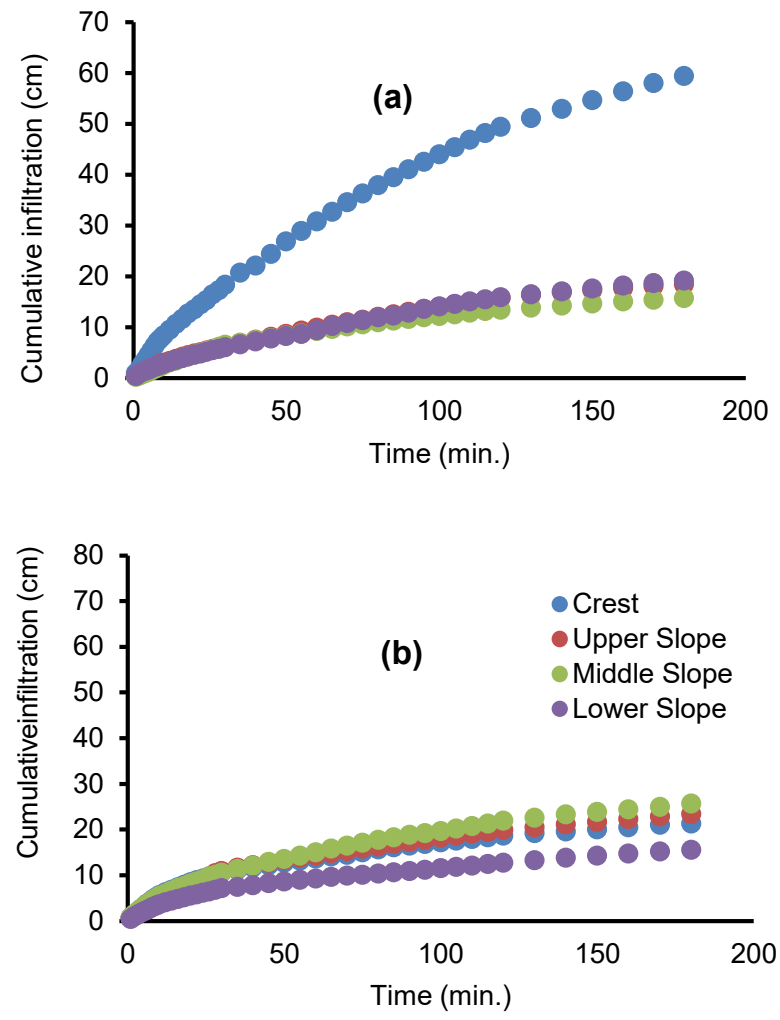

Figure 2: Effect of slope position on cumulative infiltration: (a) North-facing (NfS) and (b) South-facing slope (SfS) at the University of Uyo T\&RF.
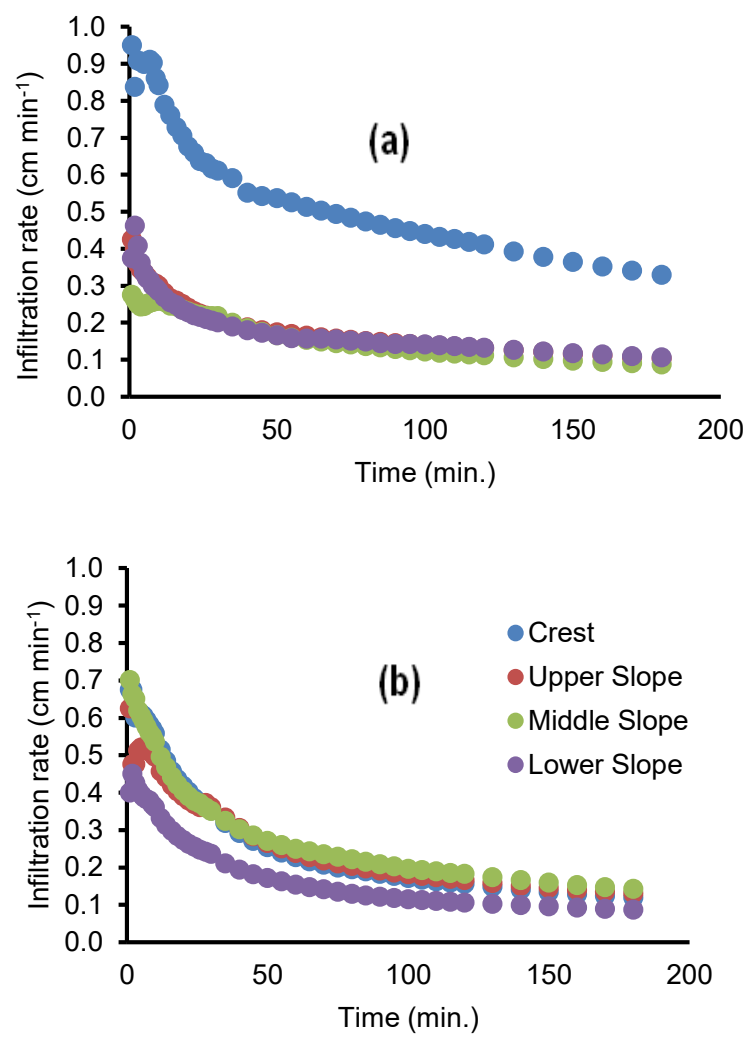

Figure 3: Effect of slope position on infiltration rate on: (a) North-facing slope (NfS) and (b) South-facing slope (SfS) at the University of Uyo T\&RF rainwater supply rate. The $S$ also decreases downslope in both NfS and SfS. Also, soil water transmissivity, $A$ was significantly $(p<0.05)$ higher at CR than UP, MS and LS slope positions, and exhibited a decreasing trend downslope (Table 2). Further, the observed effects appeared to be slope-specific.

\section{Interaction Effects of Slope Aspect and Position on Infiltration Characteristics}

The interaction effect of slope aspect and position on $i_{o}$ was erratic, i.e., it decreases and increases down slope but significantly $(p<0.05)$ higher at CR than UP, MS and LS of NfS, and significantly $(p<0.05)$ higher at MS than LS of SfS. A similar trend was observed in $i_{c}, I, S$ and $A$ and that the interactions were slope-specific.

\section{Interaction between Infiltration Characteristics and Soil Properties}

The relationships between infiltration characteristics and soil properties were generally poor or lacking (Tables 3 and 4). In Table 3 (NfS) $i_{o}$ and A were negatively $(p<0.05)$ related to SOC indicating that the latter is not critical to rainwater acceptance and transmission in the NfS soil. This observation suggests that increases in SOC adversely influence the surface and intrinsic structure of the coarse-textured soil under investigation (Ezenne et al., 2019). In Table 4 (SfS), $S$ was significantly $(p<0.05)$ positively related to TS and negatively related to silt and clay which implies that the infiltration process is governed by the coarse fragments on this slope. The $S$ is dependent on the suction gradient at the initial stages of the infiltration process, which was probably facilitated in coarsetextured soils. Thus, the relationship of infiltration and the two terms of the Philip equation and soil properties was different on the north and south slopes of the T\&RF. However, to facilitate infiltration and soil water storage, tillage to loosen the soil and surface cover of mulch to conserve the soil would be needed to improve soil physical quality and productivity for crop production on the farm.

\section{CONCLUSION}

The results of the study show that both NfS and SfS were loamy sand-textured and had a narrow texture range. There was no consistent pattern of differences in the effect of slope aspect and position on the infiltration parameters. However, the initial infiltration rate $\left(i_{o}\right)$ was significantly higher on SfS than NfS, while final infiltration rate $\left(i_{c}\right)$ and cumulative depth of water $(I)$ infiltrated were statistically similar between the slopes but higher on NfS than SfS. Soil water sorptivity $(S)$ significantly lower in NfS than SfS soil, soil water transmissivity $(A)$ was similar in NfS and SfS soil. Although there were statistical significant effects of slope and slope positions on infiltration characteristics, soil surface management practices with tillage and mulch could be applied to enhance water infiltration into the soil for increases in soil water storage and crop production on the T\&SF. 
Table 3: Correlations matrixof infiltration characteristics and soil physical properties on NfS on the University of Uyo T\&RF

\begin{tabular}{|c|c|c|c|c|c|c|c|c|c|c|c|c|c|c|}
\hline & $i_{\mathrm{o}}$ & $i_{\mathrm{f}}$ & I & $\mathrm{S}$ & $\mathrm{A}$ & FS & $\mathrm{CS}$ & TS & Silt & Clay & B.D & TP & Ksat & SOC \\
\hline$i_{\mathrm{o}}$ & 1.000 & & & & & & & & & & & & & \\
\hline $\begin{array}{l}\iota_{0} \\
i_{\mathrm{f}}\end{array}$ & $0.783^{* * *}$ & 1.000 & & & & & & & & & & & & \\
\hline I & $0.783^{* *}$ & $1.000^{* *}$ & 1.000 & & & & & & & & & & & \\
\hline S & $0.879^{* * *}$ & $0.543^{*}$ & $0.543^{*}$ & 1.000 & & & & & & & & & & \\
\hline A & $0.796^{* *}$ & $0.979^{* *}$ & $0.979^{* *}$ & $0.579^{*}$ & 1.000 & & & & & & & & & \\
\hline FS & -0.115 & -0.281 & -0.281 & 0.015 & -0.201 & 1.000 & & & & & & & & \\
\hline CS & 0.177 & 0.160 & 0.160 & 0.164 & 0.119 & $-0.754^{* \pi}$ & 1.000 & & & & & & & \\
\hline TS & 0.018 & -0.179 & -0.179 & 0.182 & -0.122 & -0.191 & $0.680^{\text {** }}$ & 1.000 & & & & & & \\
\hline Silt & -0.018 & 0.179 & 0.179 & -0.182 & 0.122 & 0.191 & $-0.680^{* * *}$ & $-1.000^{* *}$ & 1.000 & & & & & \\
\hline Clay & -0.018 & 0.179 & 0.179 & -0.182 & 0.122 & 0.191 & $-0.680^{* * \pi}$ & $-1.000^{* * *}$ & $1.000^{* *}$ & 1.000 & & & & \\
\hline B.D & 0.023 & -0.089 & -0.089 & -0.098 & -0.141 & 0.061 & 0.061 & 0.056 & -0.056 & -0.056 & 1.000 & & & \\
\hline $\mathrm{TP}$ & -0.014 & -0.050 & -0.050 & -0.030 & -0.096 & $-0.725^{* \pi}$ & $0.770^{* *}$ & $0.522^{*}$ & $-0.522^{*}$ & $-0.522^{*}$ & -0.063 & 1.000 & & \\
\hline Ksat & 0.057 & -0.129 & -0.129 & 0.090 & -0.103 & -0.495 & $0.723^{* *}$ & $0.624^{* *}$ & $-0.624^{* * *}$ & $-0.624^{* \pi}$ & -0.271 & $0.830^{* * *}$ & 1.000 & \\
\hline SOC & $-0.594^{*}$ & -0.490 & -0.490 & -0.335 & $-0.582^{*}$ & -0.002 & -0.018 & -0.135 & 0.135 & 0.135 & -0.083 & 0.013 & -0.090 & 1.000 \\
\hline \multicolumn{15}{|c|}{$\begin{array}{l}i_{\mathrm{o}}-\text { initial infiltration rate; } \mathrm{i}_{\mathrm{f}} \text { - final infiltration rate; I - cumulative infiltration; } \mathrm{S} \text { - sorptivity; A - transmissivity; FS - fine sand; CS - coarse sand; } \\
\text { TS - total sand; BD - bulk density; TP - total porosity; Ksat - saturated hydraulic conductivity; SOC - soil organic carbon }\end{array}$} \\
\hline \multicolumn{15}{|c|}{ Table 4: Correlations matrix of infiltration characteristics and soil physical properties on SfS on the University of Uyo T\&RF } \\
\hline & $i_{\mathrm{o}}$ & $i_{\mathrm{f}}$ & I & $\mathrm{S}$ & A & FS & $\mathrm{CS}$ & TS & Silt & Clay & $\mathrm{BD}$ & $\mathrm{TP}$ & Ksat & SOC \\
\hline$i_{\mathrm{o}}$ & 1.000 & & & & & & & & & & & & & \\
\hline$i_{\mathrm{f}}$ & $0.840^{* *}$ & 1.000 & & & & & & & & & & & & \\
\hline I & $0.840^{* *}$ & $1.000^{* * *}$ & 1.000 & & & & & & & & & & & \\
\hline S & $0.731^{* *}$ & 0.403 & 0.403 & 1.000 & & & & & & & & & & \\
\hline A & $0.837^{* *}$ & $0.777^{* *}$ & $0.777^{* *}$ & $0.538^{*}$ & 1.000 & & & & & & & & & \\
\hline FS & -0.028 & -0.099 & -0.099 & 0.030 & -0.020 & 1.000 & & & & & & & & \\
\hline $\mathrm{CS}$ & 0.300 & 0.074 & 0.074 & 0.409 & 0.054 & $-0.611^{*}$ & 1.000 & & & & & & & \\
\hline TS & 0.346 & 0.073 & 0.073 & $0.526^{*}$ & 0.143 & -0.256 & $0.765^{* *}$ & 1.000 & & & & & & \\
\hline Silt & -0.346 & -0.073 & -0.073 & $-0.526^{*}$ & -0.143 & 0.256 & $-0.765^{* *}$ & $-1.000^{* *}$ & 1.000 & & & & & \\
\hline Clay & -0.346 & -0.073 & -0.073 & $-0.526^{*}$ & -0.143 & 0.256 & $-0.765^{* *}$ & $-1.000^{* *}$ & $1.000^{* *}$ & 1.000 & & & & \\
\hline BD & -0.057 & -0.132 & -0.132 & -0.011 & -0.029 & $0.578^{*}$ & -0.415 & -0.459 & 0.459 & 0.459 & 1.000 & & & \\
\hline TP & 0.041 & 0.053 & 0.053 & 0.050 & -0.035 & $-0.607^{*}$ & 0.440 & 0.432 & -0.432 & -0.432 & $-0.973^{* * *}$ & 1.000 & & \\
\hline Ksat & 0.236 & 0.113 & 0.113 & 0.212 & 0.000 & -0.483 & 0.446 & 0.420 & -0.420 & -0.420 & $-0.791^{* *}$ & $0.855^{* *}$ & 1.000 & \\
\hline SOC & -0.142 & -0.049 & -0.049 & -0.102 & -0.369 & -0.384 & 0.397 & 0.081 & -0.081 & -0.081 & -0.461 & 0.479 & 0.472 & 1.000 \\
\hline
\end{tabular}

\section{REFERENCES}

Arya L.M., Leij F.G., van Genuchten M.Th. and Shouse P.J. (1999a). Scaling parameter to predict the soil water characteristic from particle-size distribution data. Soil Sci. Soc. Am. J., 63, 510-519

Arya L.M., Leij F.G., Shouse P.J. and van Genuchten M.Th. (1999b). Relationship between the hydraulic conductivity function and the particle-size distribution. Soil Sci. Soc. Am. J., 63, 1063-1070

Beckett P.H.T. and Webster R. (1971). Soil variability: a review. Soil Fertility, 34

Bonsu M. (1993). Field determination of sorptivity as a function of water content using tension infiltrometer. J. Soil Sci., 44, 411-415

Brutsaert W. (1977). Vertical infiltration in dry soil. Water Resources Research, 13(2), 363-368

Cerda A. (1996). Seasonal variability of infiltration rates under contrasting slope conditions in south-east Spain. Geoderma, 69 (3 \& 4), 217-232

Coble D.W., Milner K.S. and Marshall J.D. (2001). Above-and-below ground production of trees and other vegetation on contrasting aspects in western Montana: a case study. Forest Ecol. Manage, 142, 231-241

Davidoff B. and Selim H.M. (1986). Goodness of fit for eight water infiltration models. Soil Sci. Soc. Am. J., 50, 759-764

Dekker L.W. and Ritsema C.J. (1994). How water moves in a water repellent sandy soil: Potential and actual water repellency. Water Resour. Res., 30, 2507-2517

Dunne T., Zhang W. and Aubry B. F. (1991). Effects of rainfall, vegetation, and micro-topography on infiltration and runoff. Water Resour. Res., 27, 2271-2284

Dunne T. and Leopold L. (1978). Water in Environmental Planning. Freeman, San Francisco

Evans I.S. (1972). General Geomorphology: derivatives of altitude and descriptive statistics. In: Chorley R.J. (ed.), Spatial Analysis in Geomorphology (pp. 17-90). Matheun, London
Ezenne G.I., Obalum S.E. and Tanner J. (2019). Physical-hydraulic properties of tropical sandy-loam soil in response to rice-husk dust and cattle dung amendments and surface mulching. Hydrol. Sci. J., in press. DOI: https://doi.org/10.1080/02626667.2019.1662909

FAO (2014). World Reference Base for Soil Resources 2014. International Soil Classification System for Naming Soils and Creating Legends for Soil Maps. World Soil Resources Reports No. 106. FAO/WRB/IUSS Working Group, FAO, Rome

Flint L.E. and Flint A.L. (2002). Porosity. pp. 241-254. In: Methods of Soil Analysis. Physical Methods. Part 4. Soil Sci. Soc. Am. Book Series 5. Madison, W1, USA

Franzluebbers A.J. (2002). Water infiltration and soil structure related to organic matter and its stratification with depth. Soil Tillage Res., 66, 197-205

Gee G.W. and Or D. (2002). Particle-size analysis. In: Methods of Soil Analysis. Physical Methods, Part 4 (pp. 255-293). Soil Sci. Soc. Am. Book Series 5. Madison, W1, USA

Green W.H. and Ampt G. (1911). Studies on soil Physics. J. Agric. Sci., 4 (1), 1-24

Geroy I.J., Gribb M.M., Marshall H.P., Chandler D.G., Benner S.G. and McNamara J.P. (2011). Aspect influence on soil water storage. Hydrol. Processes, 25, 3836-3842

Gogo A. (2018). Effect of Slope on Infiltration Characteristics and Models on Coastal Plain Sand Soils in Akwa Ibom State, Nigeria. MSc Project Report, Department of Soil Science and Land Resources Management, University of Uyo, Uyo. p. 73

Grossman R. B. and Reinsch T. G. (2002). Bulk density and linear extensibility. 201-228. In: Methods of Soil Analysis. Physical Methods. Part 4. Soil Sci. Soc. Am. Book Series 5. Madison, W1, USA

Guzman J.G. and Al-Kaisi M.M. (2011). Landscape position effect on selected soil physical properties of reconstructed prairies in south-central Iowa. J. Soil Water Conserv., 66 (3), 183-191 
Hillel D. (1971). Soil and water; physical principles and processes. Academy Press, New York. p. 288

Horton R.E. (1940). Analysis of runoff-plot experiment with varying infiltration capacity. Transactions American Geophysical Union, 20, 693-711

Inyang P.E.B. (1975). Climate Regions. pp. 27-29. In: Ofomata G.E.K. (ed). Nigeria in Maps: Eastern States. Ethiope Publ. House, Midwest Mass Comm. Corp. Benin City, Nigeria

Jenny H. (1980). The soil resources: origin and behaviour. Ecol. Studies, 37. Springer-Verlag, New York. p. 377

Jungerius P.D. (1985). Soils and geomorphology. Catena Supplement, 6, 1-18

Lal R. (1986). Soil surface management in the tropics for intensive land use and high and sustained production. Advances Soil Sci., 5, 1-109

Lal R. and van Doren Jr., D. M. (1990). Influence of 25 years of continuous corn production by three tillage methods on water infiltration for two soils in Ohio. Soil Tillage Res., 16, 71-84

Lal R. and Shukla M.K. (2005). Principles of Soil Physics. Marcel Dekker, Inc., New York. p. 682

Li X.Y., Contreras S., Sole-Benet A., Canton Y., Domingo F. and Lazaro R. (2011). Controls of infiltration-runoff processes in Mediterranean karst rangelands in SE Spain. Catena, 86, 98-109

Li Z., Wu P.T., Feng H. et al. (2009). Simulated experiment on effect of soil bulk density on soil infiltration capacity. Trans. CSAE, 25 (6), 40-45 (in Chinese)

Linsley R.K., Kohler M.A. and Paulhus J.L.H. (1975). Hydrology for Engineers ( $2^{\text {nd }}$ ed). McGraw-Hill: New York. p. 482

Mbagwu J.S.C. (1997). Quasi-steady infiltration rates of highly permeable tropical moist savannah soils in relation to land use and pore-size distribution. Soil Technol., 11, 185-195

Moore I.D., Larson C.L. and Slack D.C. (1981). Modelling infiltration: a measurable parameter approach. J. Agric. Engineering Res., 26 (1), 21-32

Mukhtar S., Baker J.L., Horton R. and Erbach D.C. (1985). Soil water infiltration as affected by the use of the paraplow. Trans. ASAE, 28, 1811-1816

Ogban P.I., Maduakor O. and Akwe I.P. (2000). Infiltration characteristics and erosion potentials of catenary soils in south-eastern Nigeria. pp. 78-81. In: Proc. $26^{\text {th }}$ Annual Conf. Soil Science Society of Nigeria, University of Ibadan, Ibadan. Oct. 31 - Nov 5

Ogban P.I. and Ekerette I.O. (2001). Physical and chemical properties of the coastal plain sands of southeastern Nigeria. Nigerian J. Soil Res., 2, 6-14

Ofomata G.E.K. (1981). Actual and potential erosion in Nigeria and measures for control. In: Udo E.J. and Sobulo R.A. (eds.), Acid Sands of Southern Nigerian. Soil Science Society of Nigeria (SSSN) Special Publication, Monograph, 1, pp. 151-165

Ojanuga A.G., Lekwa G. and Akamigbo F.O.R. (1981). Survey, classification and genesis of acid sands. In: Udo E.J. and Sobulo R.A. (eds.), Acid Sands of Southern Nigeria. Soil Science Society of Nigeria (SSSN) Special Publication, Monograph, 1, pp. 1-17

Ollinger S., Smith M., Martin M., Hallett R., Goodale C. and Aber J. (2002). Regional variation in foliar chemistry and $\mathrm{N}$ cycling among forests of diverse history and composition. Ecology, 83, 339-355

Petters S.W., Adighije C.I., Essang E.B. and Ekpo I.E. (1989). A regional hydrogeological study of rural water supply options for planning and implementation of phase II: Rural Water Programme in Cross River State, Nigeria. Report for Director, Rural Dev. CRSG, Nigeria
Philip J.R. (1957). Theory of infiltration: The infiltration equation and its solution. Soil Sci., 83, 345-357

Philip J.R. (1973). Flow porous media. pp. 279-294. In: Becker E. and Mikhailov G.K. (ed.) Applied mechanics. Proc. $13^{\text {th }}$ Int. Congr. Theor. App. Mechs., Moscow. Springer, Berlin

Pla S. (2007). Infiltration. Paper presented at College on Soil Physics. Abdus Salam International Centre for Theoretical Physics. Trieste, Italy. Oct. 22 - Nov. 9

Radke J.K. and Berry E.C. (1993). Infiltration as a tool for detecting soil changes due to tillage, and grazing and livestock. Am. J. Alternative Agric., 8, 164-174

Reynolds W.D., Elrick D.E. and Youngs E.G. (2002). Ring or cylinder infiltrometer (vadose zone), pp.818-843. In: Methods of Soil Analysis, Part 4: Physical Methods. Soil Sci. Soc. Am. Book Series: 5. Madison, WI, USA

Saxton K.E., Rawls W.L., Rosenberger J.S. and Papendick R.I. (1986). Estimating generalized soil water characteristics from texture. Soil Sci. Soc. Am. J., 50, 1031-1036

Sharma M.L., Gander G.A. and Hunt C.G. (1980). Spatial variability of infiltration in a watershed. $J$. Hydrol., 45, 101-122

Shukla M.K. (2014). Soil Physics: An Introduction. CRC Press. Taylor and Francis Group. Boca Raton

Shukla M.K. (2011). Introduction to Soil Hydrology, pp. 1-23. In: M. K. Shukla (Ed.) Soil Hydrology, Land Use and Agriculture: Measurement and Modelling. CAB International, Wallingford, U.K

Shukla M.K., Lal R., Owens L.B. and Unkefer P. (2003). Land use and management imparts on structure and infiltration characteristics of soils in the north Appalachian region of Ohio. Soil Sci., 168 (3), 167-177

Sparks D. L. (1996). Methods of Soil Analysis. Part 3. Chemical Methods. Soil Science Society of America Book Series, 5, Washington DC, USA

Stewart R.D., Rupp D.E., Abou-Najm M.R. and Selker J.S. (2013). Modeling effect of initial soil moisture on sorptivity and infiltration. Water Resour. Res., 49, 7037-7047. DOI: 10.1002/Wrcr.20508, 2013

Tricker A.S. (1981). Spatial and temporal patterns of infiltration. J. Hydrol., 49, 261-277

Udosen C. (2017). Rainfall trends in a humid tropical environment. AniHap Resources, Uyo, 244

White I., Sully M. and Perroux K. (1992). Measurement of surface-soil hydraulic properties: disc permeameters, tension infiltrometers and other techniques, pp. 69-103. Adv. Measurement of Soil Physical Properties: Bringing Theory into Practice. Soil Sci. Soc. Am., Madison, USA

Webster C.C. and Wilson P.N. (1980). Agriculture in the Tropics ( $2^{\text {nd }}$ ed). Trop. Agric. Series Longmans. p. 148

Wooding R. (1968). Steady infiltration from a shallow circular pond. Water Resour. Res., 4, 1259-1273

Wuddivira H.N., Abdulkadir A. and Taminu J. (2001). Prediction of infiltration characteristics of an Alfisol in the Northern Guinea Savannah of Nigeria. Nigerian J. Soil Res., 2, 1-5

Yimer F., Ledin S. and Abdelkadir A. (2006). Soil property variations in relation to topographic aspect and vegetation community in the southeastern highlands of Ethiopia. Forest Ecol. Manage., 232, 90-99 